\title{
The Implementation of STAD Combined with Dartboard to Increase Students' Learning Outcomes and Cooperation
}

\author{
Reny Agung Pratiwi, M.V. Roesminingsih, Rr. Nanik Setyowati \\ Universitas Negeri Surabaya \\ Surabaya, Indonesia \\ reny.tiwi@yahoo.com
}

\begin{abstract}
This Study based on fact that students' ability in social studies at fifth grade is low. The aims of this study are to describe the implementation of Students' Team Achievement Division model combines with dartboard to increase students' learning outcomes and cooperation in economic activity at the fifth grade of elementary school. This study is classroom action research. This study contains two cycles. Each cycle contains four steps, there are a) planning, b) action, c) observing, and d) reflection. Data collection techniques are observation, test, and checklist. An instrument that used in this study is observation sheet, paper test, and checklist sheet. The data analysis is qualitative and quantitative. The result of this study shows that most of the student can reach the standard score. The cooperation level between students at this cycle is good. And the students' response are positive.
\end{abstract}

\section{Keywords—STAD; Dartboard; Student learning outcomes.}

\section{INTRODUCTION}

Social studies are one of the subjects taught at elementary school. At fifth grade, social studies are taught thematically integrated with other subjects. The development the core of social studies at an elementary school not only for cognition but also for simple social attitudes and skills, such as being able to observe and communicate the characteristics and connectivity of the environment and the closest community to others politely through cooperation by using technology [1].

Based on the observation, it is known that there are some problems on the fifth grade students at SDN Semolowaru IV / 614 Surabaya. These problems are a) the learning approach is teacher-centered learning, b) teacher only teach lesson that written in the book, this condition makes students tend to be a passive listener who writes and memorizes the lesson; c) there are some students who do activities outside the class because there is no motivation and interest to follow the learning; d) teachers do not use a learning media that attracts students attention, the size of the media relatively small. This has an impact on students' difficulties to observe the media were displayed by teachers.

One of the learning media that does not require a big cost, but it can be an interesting and educational media is a board throwing media or called dartboard. The dartboard can be used by teachers to create challenging and fun learning situations while accommodating the needs of students to develop their attitude, knowledge, and skills competencies. Students can perform game activities using dartboard without overriding learning activities. Simulating dartboard in learning can increase student's motivation [1][2].

Other problems encountered by the researchers is the result of students' outcome after following the learning activities do not achieve the target that has been determined. Based on the results of the daily assessment at September $16^{\text {th }}, 2017$, it is known that there are 11 students got scored below the minimum completeness criteria (KKM). There are 36 students in the VB SDN semolowaru IV/614 Surabaya. Based on this condition, it is known that almost $31 \%$ of all student at fifth grades have not reached the established KKM. For the social studies lesson, the school determined the KKM at the minimum score of 75 . This condition indicates that it needs an improvement in learning activities that have been done.

Based on the observation during the learning process, its known that the level of cooperation and awareness among students who have high academic ability with students who have the less academic ability is not optimal. Students who have the high academic ability have not shown a desire to help their friend who has less competency. In both group work and discussion activities, students with high academic ability show a dominant role, while others tend to be passive. The idea behind cooperative learning is the perception that if students want their group to succeed, they will encourage their team members to be better and will help them do it [2] [3]. Further, Slavin reveals that students are often able to do exceptional work in explaining difficult ideas by translating teacher's language into children's language. STAD can increase a student's social capability [4]. The implementation of STAD in learning can increase students' learning outcome and capability in solving a problem [3][5]. The differences between this study with the previous research are a combination of STAD with dartboard to motivate students to learn and cooperate with other student in developing their own abilities and group.

This research focussed on finding about a) how is the cooperation level between students of VB SDN Semolowaru 
IV / 614 Surabaya during the learning activity using STAD model assisted with dartboard? b) how is students' learning outcomes of VB grade at SDN Semolowaru IV / 614 Surabaya after the learning activity using STAD assisted with dartboard? and c) how is students' response during the learning activities using STAD assisted with dartboard in the increase their cooperation?

The purpose of this research is to a) describe the cooperation level between students of VB SDN Semolowaru IV / 614 Surabaya during the learning activity using STAD model assisted with dartboard; B) Describing the learning outcomes of VB SDN Semolowaru IV / 614 Surabaya after the learning activity using STAD model assisted with dartboard in order to increase student cooperation activity on economic activity material; and c) to describe the response of VB SDN Semolowaru IV / 614 Surabaya during the learning activity using STAD model assisted with dartboard in order to increase students' cooperation activity.

Students Teams Achievement Division (STAD) is one type of cooperative learning model that was developed and researched at John Hopkins University. There are three important concepts in this group learning, a) group appreciation; b) training students to have individual responsibility, and c) the equal opportunity for each group to succeed [2]. STAD is formed in five main components, there are 1) class presentations, 2) groups, 3) quiz, 4) personal progress scores, and 5) group assessment [4] [6]. Stages in STAD Cooperative Learning are a) Submission of learning objectives and learning materials; b) Students work and learn in their respective teams; c) Evaluation; and d) Team recognition (awarding).

Dartboard is one of the fixtures used in the game. Dartboard is a throwing board that is divided into three circles. The dartboard game is done by throwing arrows onto a circular board. There are three types of circles on the target board. The dartboard media is used to create a fun learning situation for students. It is expected to improve students' learning outcomes with a fun learning atmosphere [5] [7].

\section{METHOD}

This research is a classroom action research conducted through four stages in a recycling process. There are planning, action implementation, observation, and reflection. The subjects of this research are the students of VB Sekolah Dasar Negeri Semolowaru IV / 614 Surabaya that consists of 16 boys and 20 girls. This research was conducted at SDN Semolowaru IV / 614 Surabaya, Sukolilo, Surabaya, East Java. The implementation of the research started from September 2017 to May 2018.

The collecting data technique of this research are a validation sheet, observation, test, and charging questionnaire. The instrument used in this research is the validation sheet, the observation sheet about the implementation of lesson plans and student activity, assessment sheet (learning result test), and student response questionnaire. Data analysis technique used in this research is descriptive qualitative and quantitative.
There are some indicators to make a decision about the success level of this research, they are: a) the level of student classical completeness test at least reach $80 \%$ and the average classical learning outcomes reach 75 ; and b) the cooperation level of the student are more than $80 \%$.

\section{RESULTS AND DISCUSSION}

\section{A. Validation Results of the Learning Tools}

The learning equipment that was developed in this research include: lesson plan, student worksheets, Assessment Sheet, and Student's Material that are validated by 2 experts (lecturers). The result of the validator's assessment of instructional devices developed by the researcher can be seen in the table below.

TABLE 1. VALIDATION RESULT OF LEARNING EQUIPMENT
\begin{tabular}{|l|l|c|c|}
\hline No & \multicolumn{1}{|c|}{ Component } & Score & Category \\
\hline 1. & Lesson plan & 3.53 & Very good \\
\hline 2. & Student worksheets & 3.54 & Very good \\
\hline 3. & Student's material & 3.46 & Good \\
\hline 4. & Assessment sheet & 3.70 & Very good \\
\hline 5. & Learning media & 3.70 & Very good \\
\hline
\end{tabular}

The lesson plan were used in this study categorized very good with the following reasons: a) the development of the lesson plan is based on the stage of STAD learning; b) dartboard are included in the implementation of learning activities; c) the average value of the two validators to the lesson plan component reaches 3.53 with reliability of $98 \%$. An instrument is considered reliable if the percentage agreement value reaches at least 75\% [6] [8].

The Student worksheet was used in this study is very good. It is based on a validator rating that shows a value of 3.54. The Teaching Materials are quite good with the average value of both validators reached 3.46. The assessment sheets were made quite good with the average value of both validators reaching 3.70. Learning media that quite good with the average value of both validators reach 3.70.

\section{B. Student's Cooperation Level}

At the first cycle, the level of students' cooperative activities reached $70 \%$ with description a) working independently is $81 \%$; b) collaborating with members of the group is $76 \%$; c) mutual motivation among group members is $54 \%$; d) with respect to other's opinion is $67 \%$; e) making decisions based on mutual agreement is $71 \%$. Based on the results of this observation can be seen that students' cooperation activities still need to be improved. To overcome this problem, the teacher designs a learning improvement that is implemented in cycle II. The Improvements include giving attention to all students not only to active students. In addition, the teacher also informs the entire group that the successful level of the group depends on their cooperation and the responsibility of each student.

The teacher's action to overcome the cooperative problem showed a positive impact on student behavior. Based on the 
observation in cycle II, it is known that there is an increase of student cooperation activity. At the second cycle, the student cooperation activity reached $82 \%$ with description a) working independently is $85 \%$; b) collaborating with members of the group is $85 \%$; c) mutually motivate amongst the group members is $78 \%$; d) mutual appreciation is $82 \%$; e) making decisions by mutual agreement is $79 \%$. This condition is suitable with Slavin's opinion. Slavin stated that the implementation of STAD can increase the frequency of students' interaction in groups, students' motivation, develop a positive attitude among students, and increase students' achievement [6]. The comparison of students' activities in cycle I and cycle II shown in Table 2.

TABLE 2. COMPARATION ABOUT STUDENT COOPERATION
\begin{tabular}{|c|l|c|c|}
\hline \multirow{2}{*}{ No } & \multicolumn{1}{|c|}{ Cooperation Activities } & \multicolumn{2}{|c|}{ Percentage } \\
\cline { 3 - 4 } & \multicolumn{1}{c|}{ Cycle I } & Cycle II \\
\hline 1. & working independently & 81 & 85 \\
\hline 2. & $\begin{array}{l}\text { collaborating with members of the } \\
\text { group }\end{array}$ & 76 & 85 \\
\hline 3. & $\begin{array}{l}\text { mutually motivate amongst the } \\
\text { group members }\end{array}$ & 54 & 78 \\
\hline 4. & mutual appreciation & 67 & 82 \\
\hline 5. & $\begin{array}{l}\text { making a decision by mutual } \\
\text { agreement }\end{array}$ & 71 & 79 \\
\hline
\end{tabular}

Based on the observations, it is known that there is an escalation in students' activity to work independently from $81 \%$ at first cycle become $85 \%$ in the second cycle. This activity is manifested by students' activities of doing individual tasks. In cycle I, this activity appears when students work on the maps concept. Although creating maps concept is a group task, students continue to create them independently in their notebooks. In cycle II, this activity appears when students write important information contained a text material.

Collaborative activities between students in each group also increased, from $76 \%$ in the first cycle rise to $85 \%$ in the second cycle. In the first cycle, this activity is visible when students perform group activities in order to observe economic activities around students, doing the task was appeared on student worksheets I and II, and discussion with a member of each group to prepare presentation materials. In cycle II, student collaboration activities appear when students perform group activities, environmental observation activities to identify economic activities and discussions about the role of each component of economic activities. In addition, collaborative activities among students are also seen in group discussion activities as well as when students make presentations of observations. Escalation of student collaboration is in accordance with the explanation about STAD that can make students become more active to help other students in one group to collaborate in order to achieve the group success [7] [9].

Motivation activities among students increase from 54\% in cycle I to $78 \%$ in cycle II. This activity is visible during the activities in small groups. Students practice to encourage each other in one group. The teacher told the student that the success of the group depends on each individual member. STAD can make students become more active to motivate each other to improve group performance [9].
The activity of mutual respect to student opinion increase from $67 \%$ in the first cycle to $82 \%$ in the second cycle. This activity is visible when a discussion between a student in each group. In the first cycle, there are some students don't appreciate differences in groups. To overcome this situation, teachers encourage students to be able to control their emotion and accept the difference of opinion in the discussion. Furthermore, the teacher explains that differences of opinion were a natural thing in the discussion. With a difference of opinion, students can rationalize their opinions to determine the better opinion. This suggests has a positive impact on the student's ability to appreciate students disagreements in one group or with another group in the second cycle. This condition is in accordance with Superman's statement which states that through cooperative learning, students can build a good relationship with others and provide a positive outlook to others [10]. In addition, cooperative learning can also increase the cooperation between students, especially in terms of enhancing student self-esteem, as well as feelings respect and appreciation

Decision-making activities based on mutual agreement increased from $71 \%$ in cycle I to $79 \%$ in cycle II. This activity observed when a student makes a group discussion and play dartboard game. In answering questions, students are given the opportunity to discuss the answer with their group. In addition, this activity also observed when student do tasks in the group both in terms of determining the task of each group member in conducting observation, discussion, and presentation.

The following graph shows the average of student activity on cycle I and Cycle II.

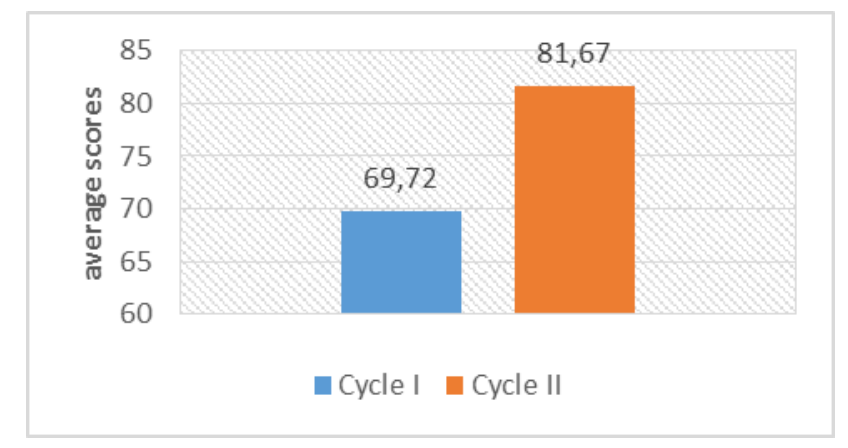

Fig. 1 Presentation of student cooperation activity

\section{Student Learning Outcomes}

The implementation of STAD with the dartboard in learning showed a positive impact on students' learning outcomes. In the first cycle, there were $69 \%$ of all students achieve the determined value of learning mastery. In this study, the determined score is 75 . In the first cycle, the students' average score reached 79,63. Although the students' average score has shown good category, there is a problem regarding the students' learning outcomes. The problem is there is a gap between students who reach standard score with students who do not reach it. In this first cycle, there is 1 child who gets a score below 50, there are 4 students got a value 
under 67, and 6 students who got a value below 75. This problem will be overcome in cycle II.

In cycle II, students who have high achievement are asked to help students who got a bad score. Students in one group are motivated to help each other in order to understand the subject matter that has been delivered. This effort shows a positive impact on the achievement of students' learning outcomes. In the second cycle, the number of students who reached standard score was $86 \%$, the number of students who did not reach standard score was $14 \%$, and the average score of students increase to 85,4. This condition is in accordance with [4] that through the STAD cooperative learning, students are trained to improve the skills or capabilities of individuals and group achievements. The following table shows the comparison of the average student learning outcomes between the first cycle and second cycle.

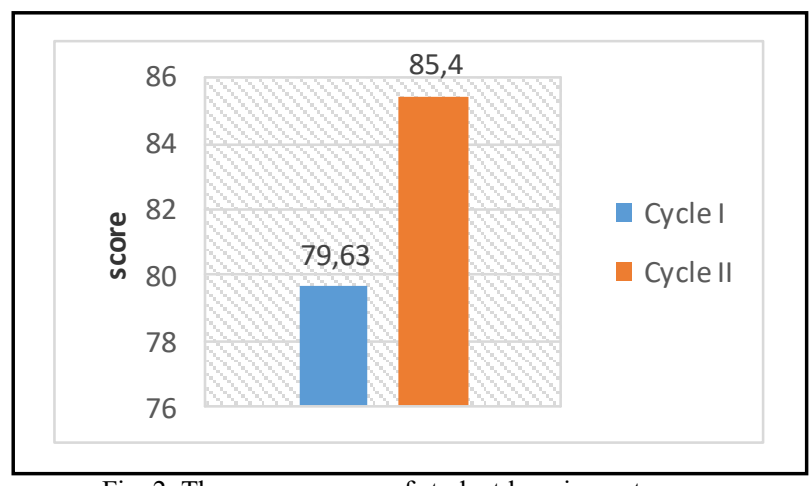

Fig. 2. The average score of student learning outcomes

The improvement of students' achievement is based on individual learning outcomes also can be known from the result of the achievement of group achievement. The group's achievement is based on the achievement of individual student scores obtained through the work of individual rating sheets and dartboard games. The following shows a data on achievement of group achievement.

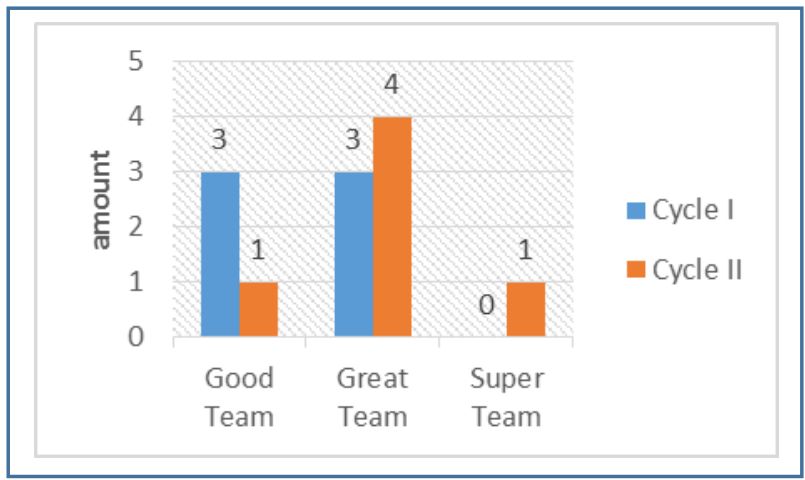

Fig. 3. Achievement of STAD Group

The results of STAD Group achievement in cycle I showed there is no group that achieved the score 25 , so no group has been awarded as a super team. In addition, there are 3 groups that achieve a group progress score between 20 and 24. This group got the title as a great team. There are 3 groups who got a progress score between 15-19. Both of these groups received the title as a good team.

In cycle II, the teacher give motivation to the students so they help each other to improve their ability of group members during the activities of deepening the subject matter in small groups. This action shows a positive impact on the achievement of group progress scores. At the second cycle, achievement of groups indicates that there is one group got progress to score over 25. This group is awarded as a super team. In addition, there are 4 teams that reach group progress scores between 20 and 24. This group got the category as a great team. There is also one group that has an average score of group progress between 15 to 19 . This group got the title as a good team. The improvement of students' ability is in accordance with Vygotsky's theory that cooperative learning enables students to be exposed to their peer thinking process; this way can not only improve the learning outcomes of all students but also help them convey their thinking processes open to all students [7]

Based on the results of changes in group achievement described above, it can be seen that STAD combined with dartboard has a positive impact on the progress of student achievement. This is in accordance with the theory presented by Slavin that stated STAD learning model accommodates equality of opportunity for each group to achieve the category as a successful team [3]. In STAD learning, students are not compared with the achievement of other group achievements, but racing with the initial ability that each group has to develop. This condition makes the opportunity for each group to achieve the category as a super team.

\section{Students Response}

The result of a questionnaire of respondents shows that $100 \%$ of respondents have the interest to follow the learning activities that have been done. With the learners' interest to follow the learning activities, the learning becomes more fun and meaningful. Daryanto and Trial explain that with the fun situation of learning activities, learners are expected to improve their learning outcomes [7].

The implementation of the learning component also shows a positive response from the students. There are $87 \%$ of all respondents stated that the students got new knowledge related to the taught material, student worksheets, and dartboard. based on this response, it known that STAD learning model and dartboard can be used as an effort to realize meaningful learning. Roger states that there are several principles used in learning activities, including students learning things that are meaningful to him [8]

\section{CONCLUSION}

Based on the results of the analysis and discussion of all research instruments, the following outlined are he conclusions of this study.

1. The level of cooperation between students of VB SDN Semolowaru IV / 614 Surabaya during the learning activities that implemented STAD combine with dartboard 
achieve a good category, $82 \%$ of the students showed cooperative behavior during the learning activities.

2. Students learning outcomes of VB grade SDN Semolowaru IV / 614 Surabaya has increased from cycle I to cycle II. In the first cycle of student learning outcomes reach 79,63 and in the second cycle reach 85.4 with the level of classical mastery learning reach $86 \%$.

3. Students Response during the learning that implements STAD learning models assisted dartboard is positive.

\section{ACKNOWLEDGMENT}

On this occasion, the author expressed her appreciation and gratitude to the distinguished Prof. Dr. Warsono, MS, the Rector of Universitas Negeri Surabaya. Prof. Dr. Ismet Basuki, M.Pd as Director of Post Graduate Universitas Negeri Surabaya. The author also thanks, Prof. Dr. MV. Roesminingsih, M.Pd. as Lecturer I and Dr. Hj. Raden Roro Nanik Setyowati, M.Si as lecturer II who have been patient and take the time to give guidance to the author, and students who are interested in the discussion related to this thesis.

\section{REFERENCES}

[1] N. A. P. Cahyani, K. Bariyyah, and L. Latifah, "Efektivitas Teknik Permainan Simulasi dengan Menggunakan Media Dart Board untuk Meningkatkan Motivasi Belajar Siswa Kelas VII C SMP Negeri 2 Tegal Siwalan Probolinggo," JKI (Jurnal Konseling Indones., vol. 3, no. 1, pp. 22-27, 2017.

[2] R. E. Slavin, "Cooperative learning teori, riset dan praktik," Bandung Nusa Media, vol. 236, 2005.

[3] T. Rattanatumma and V. Puncreobutr, "Assessing the Effectiveness of STAD Model and Problem Based Learning in Mathematics Learning Achievement and Problem Solving Ability.," J. Educ. Pract., vol. 7, no. 12, pp. 194-199, 2016.

[4] S. Sharan, "Handbook of Cooperative Learning: Inovasi pengajaran dan pembelajaran untuk memacu keberhasilan siswa di kelas," Yogyakarta. Imperium, 2009.

[5] T. Daryanto, "Konsep Pembelajaran Kreatif," Yogyakarta Gava Media, 2012.

[6] G. D. Borich, Observation skills for effective teaching: research-based practice. Routledge, 2016.

[7] A. Shoimin, "model pembelajaran inovatif dalam kurikulum 2013." Yogyakarta: Ar-Ruzz Media, 68AD.

[8] M. Nur and P. R. Wikandari, "Pengajaran berpusat kepada siswa dan pendekatan konstruktivis dalam pengajaran," Surabaya: Unesa, 2000. 